\title{
Sistem Pemantauan dan Pengendalian Modul Automatic Transfer Switch (ATS) Melalui Android Berbasis Arduino
}

\section{Automatic Transfer Switch (ATS) Module Monitoring and Control System Through Android Based on Arduino}

\author{
Reksa Pandu Wibawa Putra ${ }^{1 *}$, Muhammad Mukhsim² ${ }^{2}$ Faqih Rofii ${ }^{3}$ \\ ${ }^{1,2,3}$ Teknik Elektro, Universitas Widyagama Malang \\ Jl. Taman Borobudur Indah No.03 Malang 65142 \\ pandureksa2019@gmail.com ${ }^{1 *}$, 07.mukhsin@gmail.com² ${ }^{2}$ faqih@widyagama.ac.id ${ }^{3}$
}

\begin{abstract}
Abstrak - Automatic Transfer Switch (ATS) merupakan peralatan yang memindahkan beban ke sumber listrik cadangan ketika terjadi gangguan pada sumber utama dan sebaliknya. Dalam penelitian ini dirancang sebuah ATS menggunakan Arduino Nano sebagai kontroler, NodeMCU sebagai piranti Internet Of Things (IoT) untuk komunikasi dari android ke modul ATS, PZEM 004-t sebagai modul sensor tegangan dan arus, relai AC 10 Ampere sebagai sensor info tegangan masuk dan kontak utama, modul relai DC sebagai transfer switch antara beban dengan PLN atau generator cadangan, serta aplikasi Blynk untuk menampilkan hasil pemantauan dan berfungsi juga sebagai pengendalian manual melalui android. Hasil pengujian menunjukkan bahwa ATS bekerja ketika terjadi pemadaman PLN dan memindahkan suplai tegangan listrik dari generator cadangan ke beban dengan kesalahan pembacaan tegangan $1.0 \%$ dan arus sebesar 1.0\%. Sistem pengaman dari gangguan overload dan downvoltage bekerja ketika arus melebihi batasan 3 Ampere atau tegangan kurang dari 200 Volt, suplai beban terputus oleh relai DC dan menampilkan notifikasi teks dan notifikassi dering pada handphone.
\end{abstract}

Kata Kunci: Automatic Transfer Switch (ATS), Internet of Things (IoT), PZEM 004-t, Blynk.

\begin{abstract}
Automatic Transfer Switch (ATS) is a device that transfers loads to a backup power source when there is interference with the main source and otherwise. ATS in this study was designed using Arduino Nano as controller, NodemCU as Internet of Things (IoT) device for communication from Android to ATS modules, PZEM 004-t as voltage and current sensor module, AC 10 Ampere relay as input voltage sensor and main contact, DC relay module as a transfer switch between and PLN or backup generator, and Blynk application to display monitoring results and also functions as manual control by Android. The test results show that ATS works when a PLN outage occurs and moves the supply of voltage from the backup generator to the load with a $1.0 \%$ voltage reading error and a current reading error of $1.0 \%$. The protection system of overload and down-voltage interference works when the current over the limit of 3 Ampere or the voltage is less than 200 Volt, the supply of the load is cut off by the DC relay and displays text notifications and notifications on the handphone.
\end{abstract}

Keywords: Automatic Transfer Switch (ATS), Internet of Things (IoT), PZEM 004-t, Blynk.

TELKA, Vol.5, No.1, Mei 2019, pp. 43 54

ISSN (e): 2540-9123

ISSN (p): 2502-1982 


\section{Pendahuluan}

Sistem cadangan/backup catudaya mutlak diperlukan pada perangkat elektronika yang memerlukan energi listrik yang tidak terhenti. Cadangan catudaya digunakan untuk menggantikan sumber utama PLN. Pada penerapannya diperlukan sebuah perangkat pendukung berupa Automatic Transfer switch (ATS) untuk melakukan pensaklaran dari sumber utama ke cadangan catu daya atau sebaliknya [1]. Beberapa penelitian tentang ATS telah dilakukan seperti pada penelitian "Rancang Bangun Dan Implementasi Automatic Transfer Switch (ATS) Menggunakan Arduino Uno dan Relai" Oleh Robinzon Pakpahan dari Universitas Telkom yang dapat memantau kondisi sumber listrik, besar tegangan, dan arus pada sistem ATS melalui web browser. Seiring perkembangan teknologi yang serba praktis dan online, maka pada penelitian dan perancangan Sistem Pemantauan dan Pengendalian Modul ATS Berbasis Android dengan memanfaatkan sistem Internet Of Things (IoT), memungkinkan sumber listrik dan besaran listrik dapat dipantau dan dikontrol oleh sebuah sebuah sistem ATS dari jarak jauh melalui internet. Oleh sebab itu untuk mengembangkan sistem rancang bangun sistem ATS, maka dilakukan penilitian dengan judul "Sistem Pemantauan dan Pengendalian Modul Automatic Transfer Switch (ATS) Melalui Android Berbasis Arduino". Kelebihan dalam penelitian ini yaitu sistem akan dapat memantau dan mengendalikan modul ATS hanya dengan menggunakan smartphone Android melalui jaringan internet. Selain hal tersebut alat ini juga dapat memproteksi bila terjadi drop tegangan sumber listrik yang dapat berdampak kerusakan pada alat-alat elektronik atau sebagai beban dan kelebihan beban yang dapat merusak alat ini sendiri. Hal ini memungkinkan seorang operator dapat mengendalikan dan memantau sumber listrik melalui ATS, dimanapun dan kapanpun selama terhubung ke internet dan sebagai proteksi beban jika terjadi gangguan listrik. Penelitian ini menggunakan 1 modul PZEM004-t sebagai sensor arus dan tegangan yang memungkinkan dapat memaksimalkan hasil pembacaan arus dan tegangan. Dengan kelebihan dan keunggulan tersebut, alat ini dapat diandalkan sebagai perangkat otomatis di rumah tangga.

\section{Metode Penelitian}

\subsection{Diagram Blok}

Berikut diagram blok dari sistem yang digambarkan pada Gambar 1 di bawah ini :

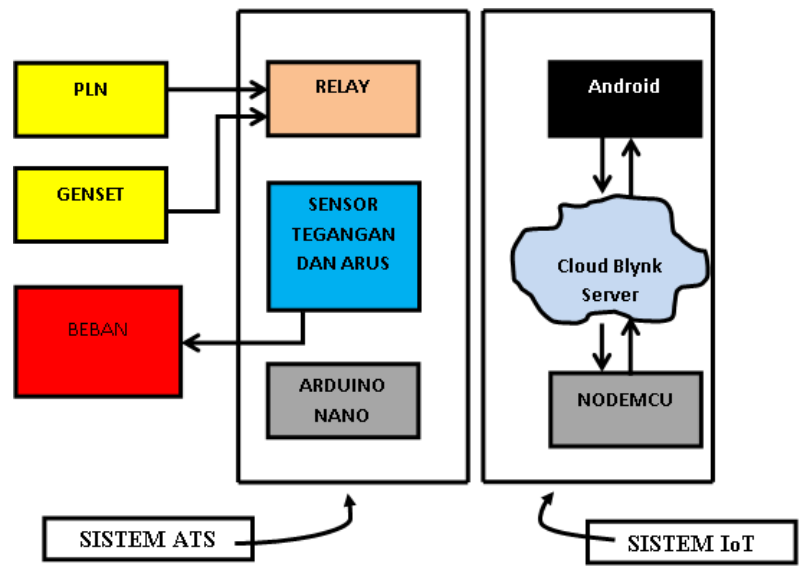

Gambar 1. Diagram blok ATS dengan Sistem IoT.

Sebelum membahas skema kerja dalam penelitian ini, berikut ini dideskripsikan terlebih dulu perangkat yang digunakan.

\subsubsection{Automatic Transfer Switch (ATS)}

Automatic Transfer Switch merupakan rangkaian control sakelar switch yang berguna untuk menghubungkan beban ke sumber tegangan listrik alternatif ketika PLN padam. Pemakaian panel ATS ini dibedakan pada besar kecilnya pemakaian listrik. Semakin tinggi pemakaian daya listrik, 
tentunya akan semakin besar pula spesifikasi komponen-komponennya terutama breaker dan kontaktornya dan juga ukuran kabelnya [2].

\subsubsection{Internet of Things (IoT)}

Internet of Things (IoT) adalah suatu konsep di mana konektifitas internet dapat bertukar informasi satu sama lainnya dengan benda-benda yang ada di sekelilingnya. Internet of Things (IoT) akan lebih mempermudah kegiatan manusia dalam melakukan berbagai aktifitas sehari-hari [3]. Semua kegiatan dapat dilakukan dengan sangat praktis dan di satu sisi adanya sistem kontrol karena perangkat yang terhubung menyebabkan kehidupan akan lebih efektif dan efisien. Salah satu Perangkat IoT yang digunakan dalam penelitian ini adalah NodemCU [4].

\subsubsection{Arduino Nano}

Arduino Nano adalah salah satu papan pengembangan mikrokontroler yang berukuran kecil, lengkap dan mendukung penggunaan breadboard. Arduino Nano kurang lebih memiliki fungsi yang sama dengan Arduino Duemilanove, tetapi dalam paket yang berbeda [5]. Arduino Nano tidak menyertakan colokan DC berjenis Barrel Jack, dan dihubungkan ke komputer menggunakan port USB Mini-B. Arduino Nano dirancang dan diproduksi oleh perusahaan Gravitech. Gambar 2 merupakan bentuk fisik Arduino Nano.

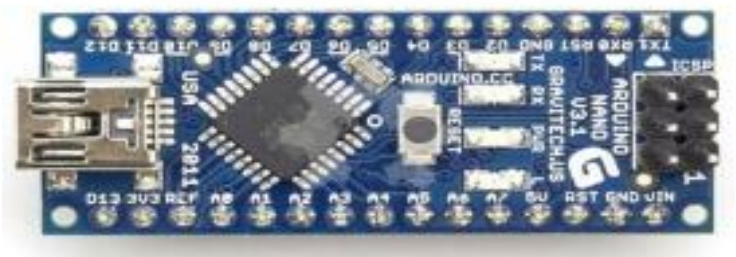

Gambar 2. Arduino tampak depan [6].

\subsubsection{NodemCU}

NodeMCU merupakan sebuah open source platform IoT dan pengembangan kit dari ESP8266 yang menggunakan bahasa pemrograman Lua untuk membantu dalam membuat prototype produk IoT atau bisa dengan memakai sketch dengan adruino IDE [7]. Karena jantung dari NodeMCU adalah ESP8266 (khususnya seri ESP-12, termasuk ESP-12E) maka fitur - fitur yang dimiliki NodeMCU akan kurang lebih sama ESP-12 (juga ESP-12E untuk NodeMCU v.2 dan v.3) kecuali NodeMCU telah dibungkus oleh API sendiri yang dibangun berdasarkan bahasa pemrograman Lua, yang kurang lebih cukup mirip dengan javascript. Gambar 3 merupakan bentuk fisik dari NodemCU.

\subsubsection{Modul PZEM004 - T}

Modul PZEM 004 - T adalah sebuah modul sensor multifungsi yang berfungsi untuk mengukur daya,tegangan, arus dan energi yang terdapat pada sebuah aliran listrik. Modul ini sudah dilengkapi sensor tegangan dansensor arus (CT) yang sudah terintegrasi [9]. Dalam penggunaannya, alat ini khusus untuk penggunaan dalam ruangan (indoor) dan beban yang terpasang tidak diperbolehkan melebihi daya yang sudah ditetapkan [10]. Bentuk fisik dari PZEM004-t dapat dilihat pada Gambar 4. 


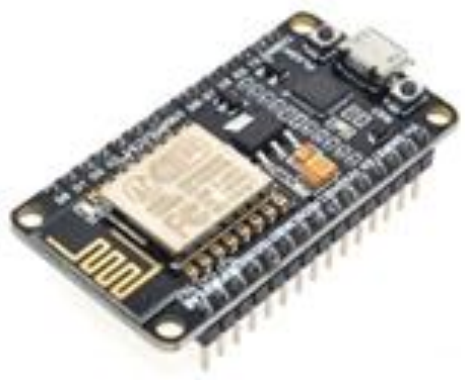

Gambar 3. NodeMCU Arduino[8].

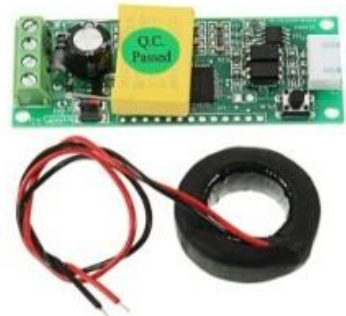

Gambar 4. Modul PZEM004-t [9].

\subsubsection{Software Aplikasi Android Blynk}

Blynk adalah sebuah layanan server yang digunakan untuk mendukung project Internet of Things. Layanan server ini memiliki lingkungan mobile user baik Android maupun iOS. Blynk adalah dashborad digital dengan fasilitas antarmuka grafis dalam pembuatan project-nya. Penambahan komponen pada Blynk Apps dengan cara Drag and Drop sehingga memudahkan dalam penambahan komponen Input/output tanpa perlu kemampuan pemrograman Android maupun iOS [11].

Blynk diciptakan dengan tujuan untuk control dan monitoring hardware secara jarak jauh menggunakan komunikasi data internet ataupun intranet (jaringan LAN). Kemampuna untuk menyimpan data dan menampilkan data secara visual baik menggunakan angka, warna ataupun grafis semakin memudahkan dalam pembuatan project dibidang Internet of Things.

\subsection{Cara Kerja Alat}

Kondisi awal, sumber listrik utama PLN merupakan sumber nyata. Tegangan PLN dalam kondisi ON akan mengalir ke sistem, dan mengaktikan sebuah relay AC yang terkoneksi dengan Arduino Nano untuk memantau status PLN. Selanjutnya besar listrik PLN akan dibaca oleh sebuah sensor tegangan dan arus. Data pembacaan dari sensor tersebut akan dikirim oleh Arduino Nano yang diteruskan ke NodemCU dan Cloud server Blynk untuk ditampilkan melalui aplikasi Android. Aplikasi Blynk Android akan menampilkan besar tegangan dan arus serta menampilkan status PLN ON dan GENERATOR CADANGAN OFF melalui indikator LED dari sumber energi listrik.

Kondisi kedua, sumber listrik utama PLN OFF,secara otomatis akan mengaktifkan sebuah relai starting generator cadangan sebagai sumber listrik cadangan. sumber listrik generator cadangan merupakan simulasi dari sumber PLN. Tegangan dari generator cadangan akan masuk dan mengaktifkan sebuah relay AC yang terkoneksi dengan Arduino Nano untuk memantau status generator cadangan. Selanjutnya besar listrik generator cadangan akan dibaca oleh sebuah sensor tegangan dan arus. Data pembacaan dari sensor tersebut akan dikirim oleh Arduino Nano yang diteruskan ke NodemCU dan Cloud server Blynk untuk ditampilkan melalui aplikasi Android. Aplikasi Blynk Android akan menampilkan besar tegangan dan arus serta menampilkan status PLN OFF dan GENERATOR CADANGAN ON melalui indicator LED dari sumber energi listrik.

Kondisi ketiga ketika PLN OFF dan GENERATOR CADANGAN gagal ON. Pada kondisi ini akan dilakukan pengulangan starting generator cadangan sebanyak 4 kali. Sesudah dilakukan 4 kali starting namun GENERATOR CADANGAN masih keadaan OFF maka akan mengaktifkan peringatan berupa buzzer.

Kondisi selanjutnya ketika kelebihan beban atau terjadi penurunan tegangan dari sumber listrik utama PLN maupun dari generator cadangan. Pada kondisi ini sistem akan memproteksi beban dengan memutuskan jaringan dari sumber ke beban dengan batasan arus dan tegangan yang aman dan sudah ditentukan oleh sistem. 


\subsection{Flowchart Sistem Kerja}

Sistem kerja ATS digambarkan dengan diagram alir / flowchart pada Gambar 5, dan sistem kerja dari Blynk Aplikasi digambarkan dengan flowchart pada Gambar 6.

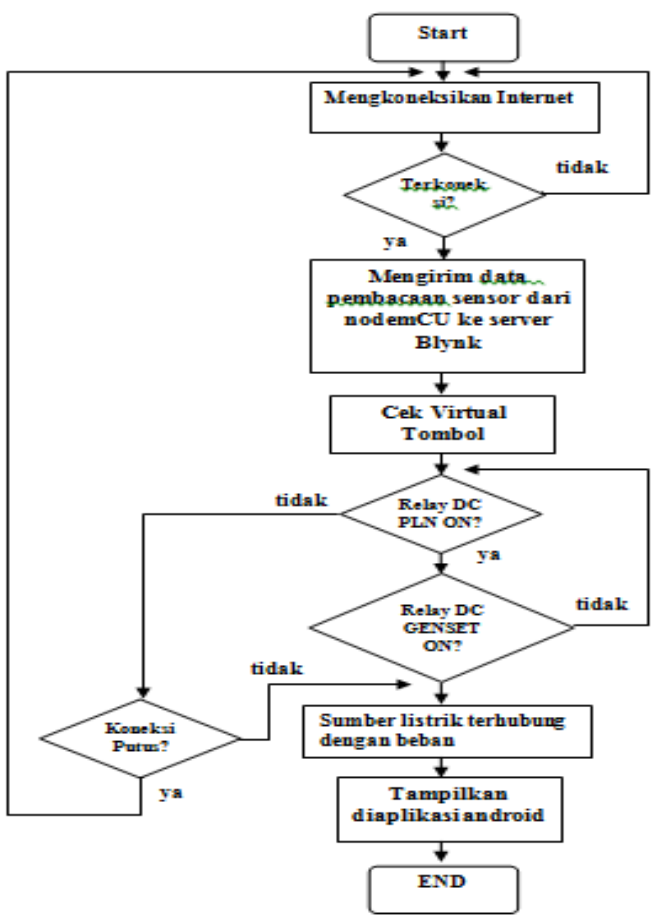

Gambar 5. Flowchart sistem ATS.
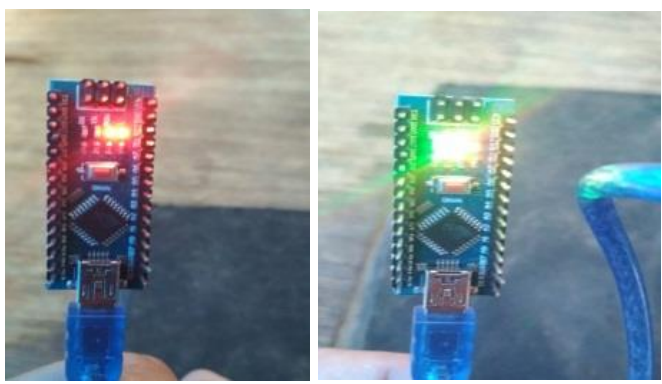

Gambar 7. Pengujian Arduino Nano.

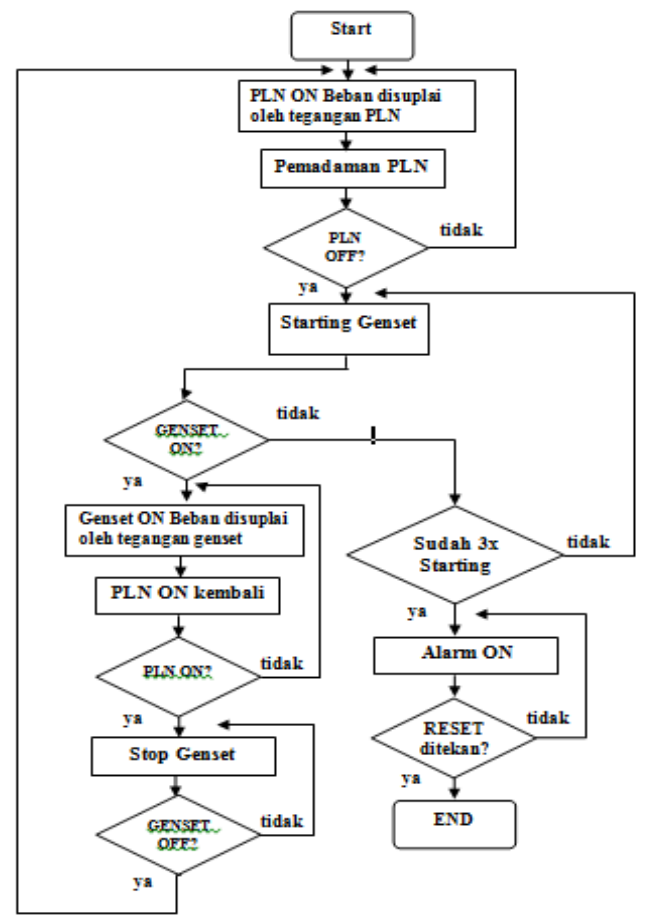

Gambar 6. Flowchart sistem pemantauan dan pengendalian dengan Blynk.
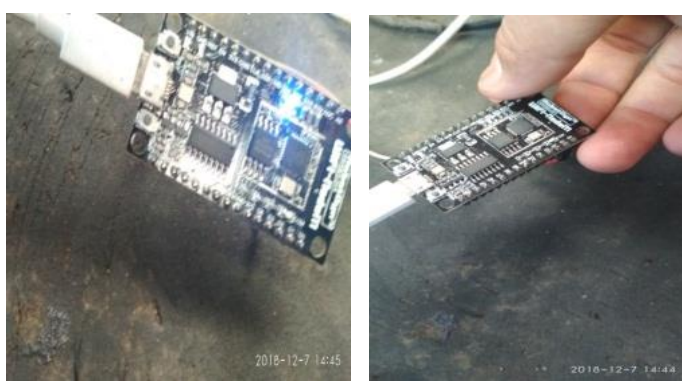

Gambar 8. Pengujian NodemCU sebagai Output.

\section{Hasil dan Pembahasan}

\subsection{Pengujian Arduino Nano}

Pengujian ini dilakukan untuk mengetahui Arduino Nano dapat bekerja secara normal. Dengan menerapkan coding Blink dari Arduino IDE yang akan menerapkan nyala berkedip pada LED indicator yang terdapat pada Board Arduino Nano itu sendiri. Pengujian Arduino Nano dapat dilihat pada Gambar 7.

\subsection{Pengujian NodemCU}

Pada pengujian ini dilakukan untuk mengetahui NodemCU dapat digunakan dengan normal, pada pengujian ini sebuah LED pada mainboard NodemCU itu sendiri dijadikan sebagai indikator menyala berkedip. Pengujian NodeMCU sebagai output dapat dilihat pada Gambar 8. 


\subsection{Pengujian PZEM 004T}

\subsubsection{Pengujian Tegangan Modul PZEM 004T}

Pada proses pengujian tegangan modul PZEM 004T dilakukan dengan menghubungkan modul PZEM 004T dengan mikrokontroller arduino nano. Setelah di hubungkan maka dilakukan pengukuran tegangan menggunakan Voltmeter dan selanjutnya dibandingkan dengan hasil pengujian modul pzem 004t dapat di tampilkan pada Serial Monitor yang ada pada program IDE. Pengujian sensor tegangan modul PZEM 004-t dapat dilihat pada Gambar 9.

\subsubsection{Pengujian Arus Modul PZEM 004T}

Selanjutnya dilakukan pengukuran arus dengan multimeter dan dibandingkan dengan serial monitor. Pengujian sensor arus modul PZEM 004-t dapat dilihat pada Gambar 10.

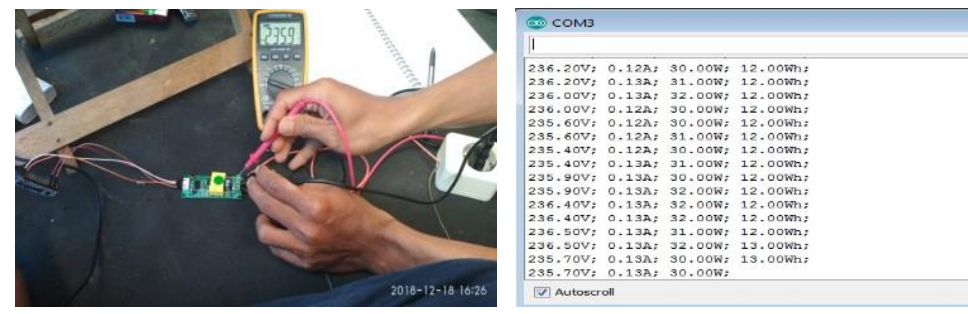

Gambar 9. Pengujian sensor tegangan modul PZEM 004-t.
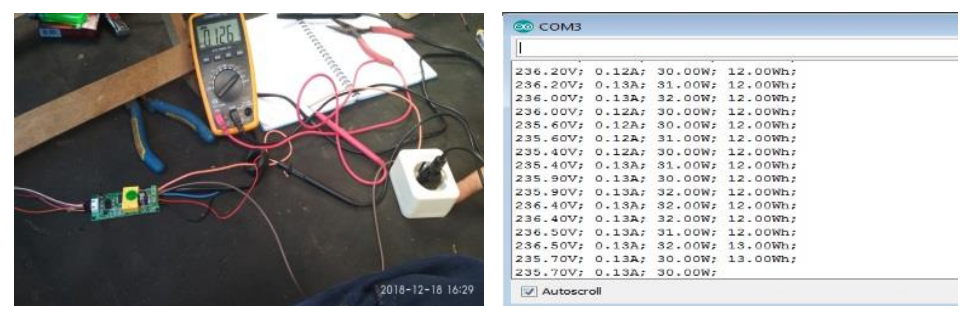

Gambar 10. Pengujian Sensor Arus Modul PZEM 004-t.

\subsection{Pengujian Aplikasi Blynk dan Relai DC}

Pada tahap ini dilakukan pengujian aplikasi android Blynk yang akan dapat mengendalikan relay. Dengan menggunakan fitur komponen switch yang terdapat di aplikasi akan dapat mengaktifkan dan menonaktifkan sebuah modul relay. Pengujian aplikasi Blynk dan relai DC dapat dilihat pada Gambar 11 dan Gambar 12.

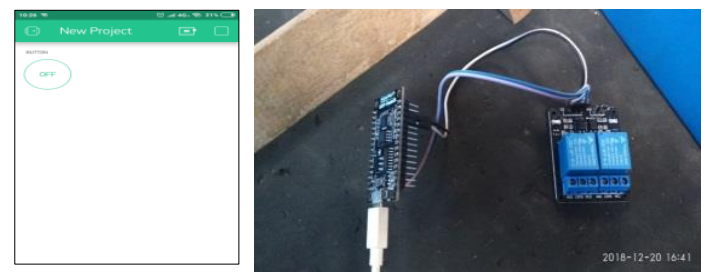

Gambar 11. Pengujian Aplikasi Blynk dan Relay DC ketika tombol OFF.
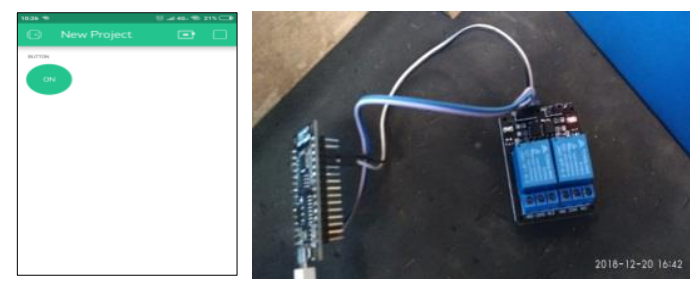

Gambar 12. Pengujian Aplikasi Blynk dan Relay DC ketika tombol ON. 


\subsection{Pengujian Keseluruhan Sistem}

Pengujian keseluruhan alat yaitu dengan menggabungkan keseluruhan perangkat keras meliputi arduino nano, nodemCu, sensor PZEM004, dan relay-relay yang dikombinasikan dengan perangkat lunak untuk menampilkan hasil dari pengujian keseluruhan. Selanjutnya mengkonfigurasikannya dengan perangkat lunak, dan coding Arduino dapat di-upload pada board masing-masing yaitu Board Arduino Nano dan Board NodemCU. Pengujian yang dilakukan menguji sistem kerja ATS dan sistem proteksi overload dan downvoltage. Gambar 13 (a) merupakan hasil dari perancangan hardware dan 13 (b) merupakan hasil perancangan tampilan aplikasi Blynk pada Android.

\subsubsection{Pengujian ATS Mode Otomatis dan simulasi aplikasi Blynk}

Pada kondisi awal sumber PLN menyuplai beban dengan mengaktifkan relay PLN. Gambar 14 merupakan hasil pemantauan aplikasi Blynk berupa tampilan besar tegangan dan arus serta kondisi sumber listrik PLN ON pada modul.

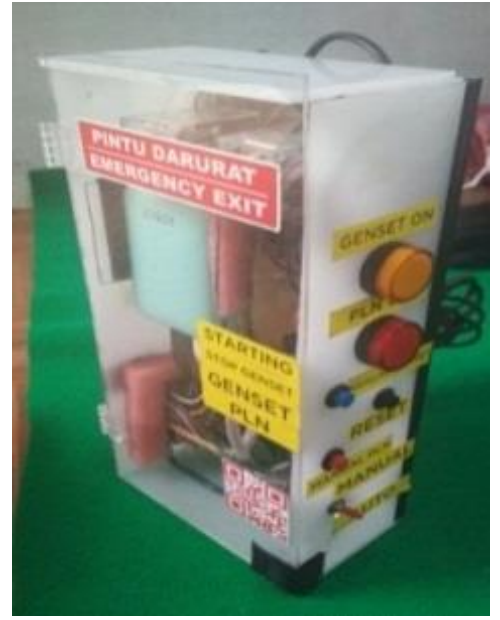

(a)

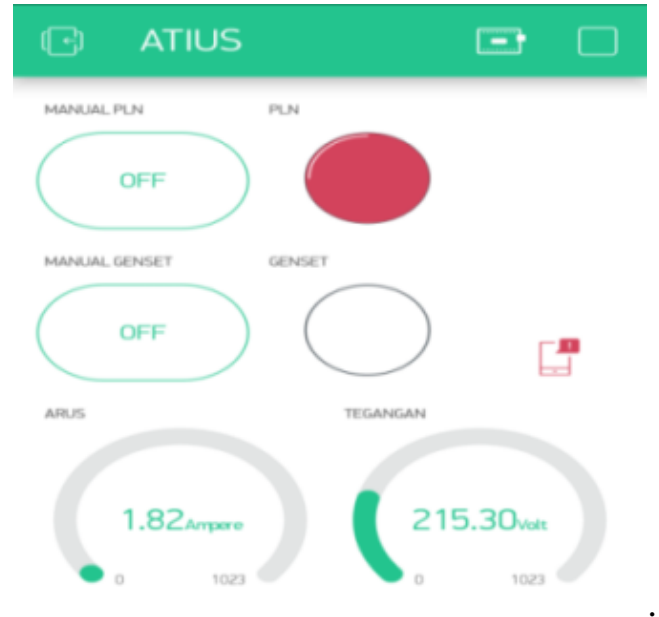

(b)

Gambar 13. (a). Prototype Hardware ATS

(b). Tampilan Software Blynk sebagai pemantau dan pengendali

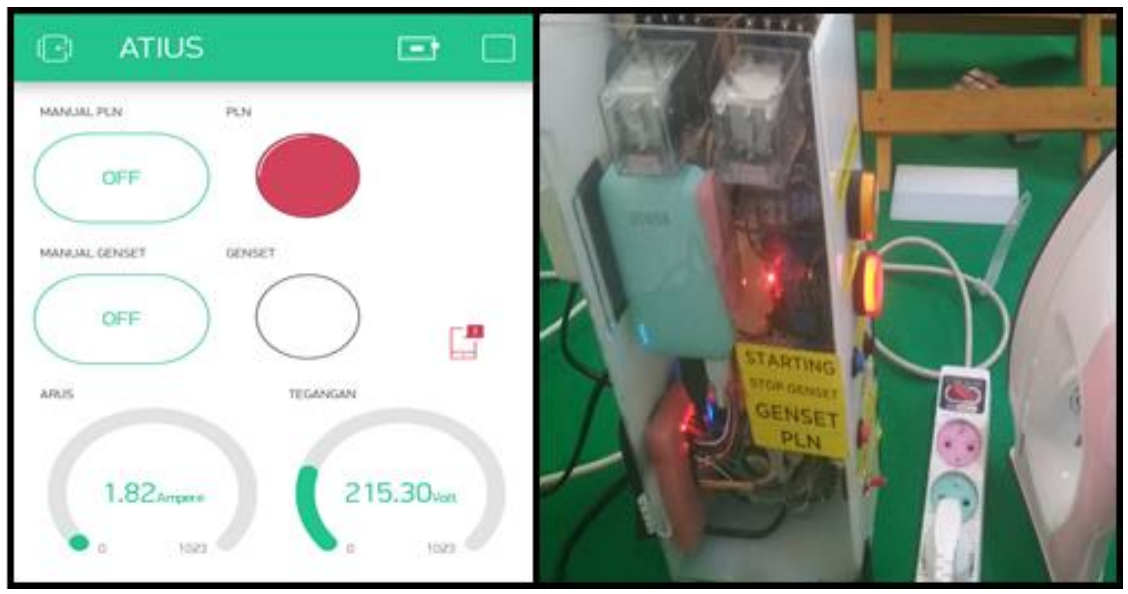

Gambar 14. Hasil Monitoring di Tampilan Aplikasi Blynk ketika PLN ON dan menyuplai Beban. 
Indikator Relay DC4 sebagai indikator PLN aktif sehingga beban disuplai oleh tegangan PLN. Selanjutnya terjadi pemadaman listrik PLN dan secara otomatis relay Starting akan bekerja untuk menyalakan genset dan dengan jeda waktu 10 detik yang telah ditentukan relay Genset akan aktif. Gambar 15 menunjukkan kondisi starting genset dengan mengaktifkan relai DC 1.

Indikator Relay DC3 berfungsi sebagai indikator Genset aktif sehingga beban disuplai oleh tegangan Genset. Gambar 16 merupakan tampilan aplikasi Blynk ketika genset sedang ON.

Gambar 17 merupakan kondisi ketika PLN ON kembali setelah pemadaman listrik. Sehingga otomatis relai DC 2 akan aktif dan mematikan genset. Pada kondisi selanjutnya ketika genset sedang ON dan PLN kembali ON maka sistem akan otomatis mematikan genset dengan mengaktifkan relay Stop Genset dan mengaktifkan relay PLN. Beban kembali tersuplai oleh tegangan PLN.

Pengujian selanjutnya ketika PLN OFF tetapi Genset tidak bisa ON maka akan dilakukan pengulangan starting sebanyak 4 kali. Jika dalam pengulangan starting tersebut genset masih belum ON maka buzzer peringatan akan berbunyi, dan untuk mematikan alar buzzernya dengan menekan tombol RESET. Gambar 18 merupakan kondisi ketika alarm ON dan tombol reset ditekan untuk mematikan alarm.

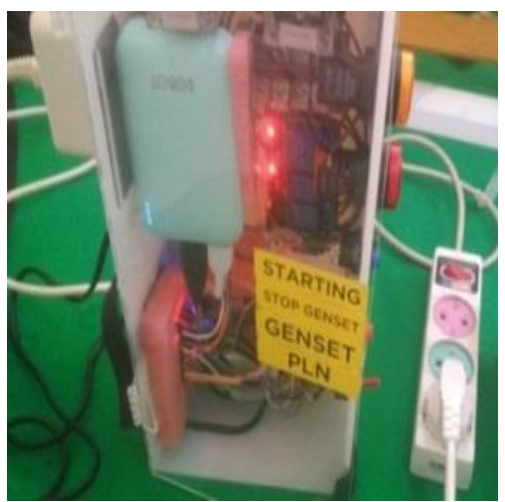

Gambar 15 Kondisi Starting Genset saat PLN OFF.

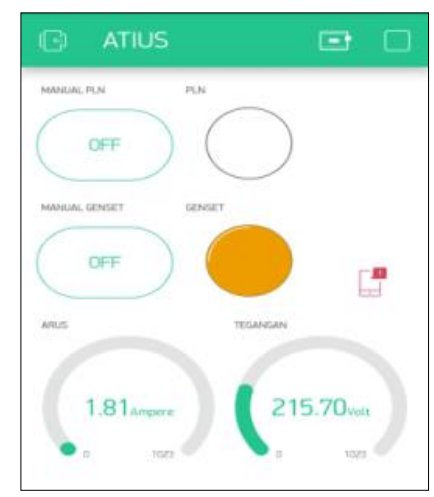

Gambar 16. Hasil Monitoring di Tampilan Aplikasi Blynk ketika GENSET ON dan menyuplai Beban.

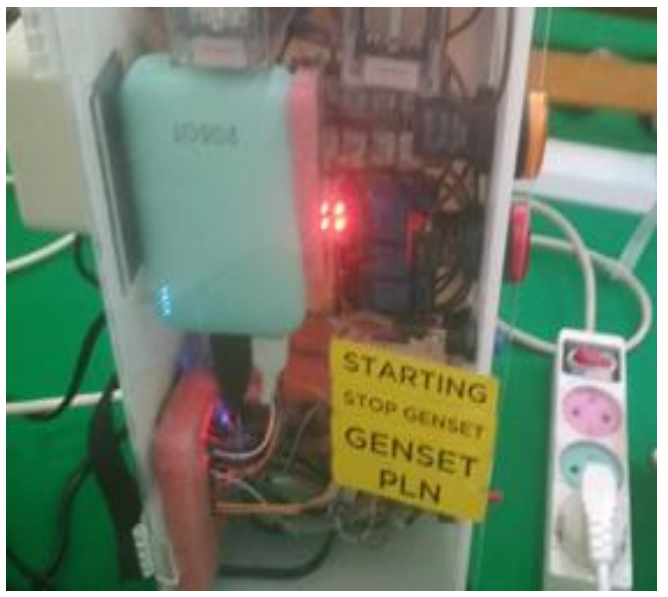

Gambar 17. Kondisi ketika PLN kembali ON.

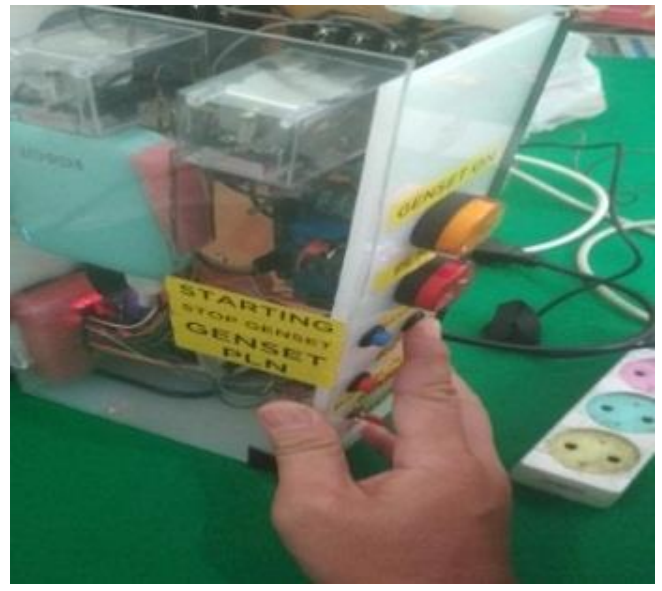

Gambar 18. Tombol reset ditekan untuk mematikan alarm.

\subsubsection{Pengujian ATS Mode manual dan simulasi aplikasi Blynk}

Pada kondisi awal, relay pengendali dalam kondisi OFF. Selanjutnya dilakukan pengendalian PLN ON dengan menekan tombol PLN ON pada modul atau dengan tombol virtual 
manual PLN pada aplikasi untuk menghubungkan sumber listrik PLN dengan beban. Gambar 19 merupakan pengendalian modul ATS dengan mengaktifkan sumber tegangan PLN.

Selanjutnya menghidupkan genset secara manual dengan menekan tombol GENSET ON untuk menghubungkan sumber listrik PLN dengan beban, maka relay starting akan ON untuk menghidupkan genset dan dengan jeda waktu 10 detik yang telah ditentukan maka Relay genset akan ON untuk menghubungkan sumber listrik genset dengan beban. Gambar 20 merupakan pengendalian modul ATS dengan mengaktifkan sumber tegangan genset.

Tabel 1 merupakan hasil pengujian yang menyatakan kondisi awal adalah PLN ON sebagai sumber listrik utama untuk menyuplai beban. Sehingga Relay AC 1 dan Relay DC 4 ON dan tegangan terhubung dengan beban. Selanjutnya ketika PLN OFF, Relay AC 1 OFF dan relay DC 1 ON selama 3 detik untuk melakukan starting. Ketika genset ON, relay AC 2 akan ON tetapi belum menyuplai beban. Setelah 10 detik relay DC 3 akan ON dan tegangan terhubung ke beban. Ketika PLN kembali ON maka relay AC 1 ON, relay DC 2 ON selama 3 detik untuk mematikan genset dan relay DC 4 ON sehingga beban kembali tersuplai oleh tegangan PLN. Selanjutkan ketika PLN OFF dan genset gagal ON maka relay AC 1 dan AC 2 akan OFF, relay DC 1 akan ON untuk melakukan starting dengan pengulangan sebanyak 4 kali. Ketika sudah dilakukan 4 kali pengulangan tapi genset belum ON, Buzzer ON.
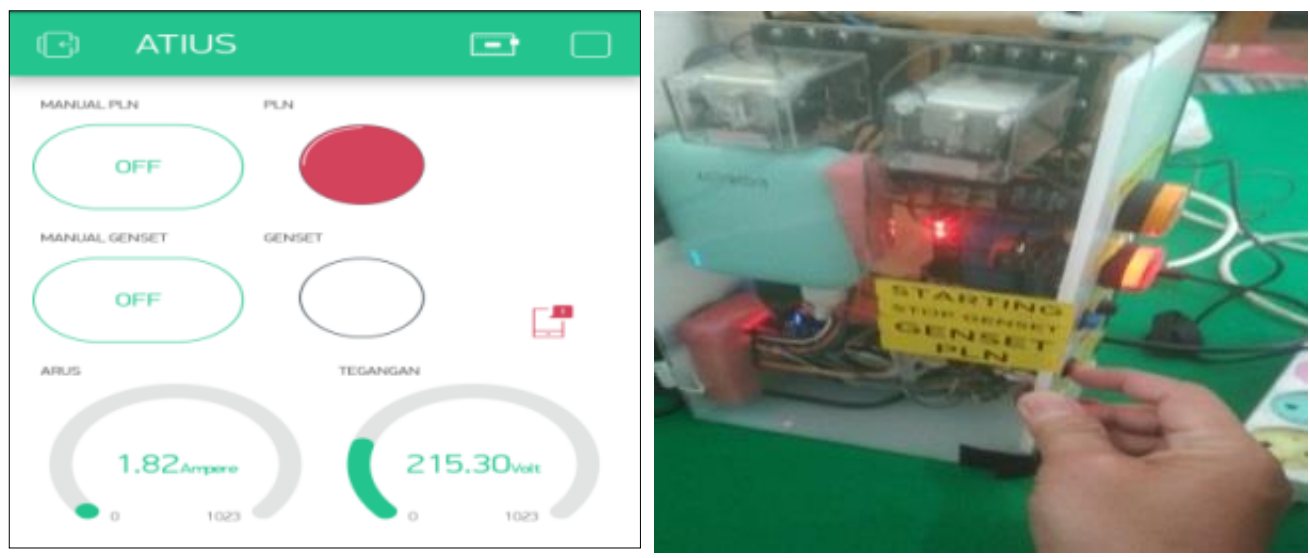

Gambar 19. Kondisi ketika PLN ON secara manual menyuplai beban.
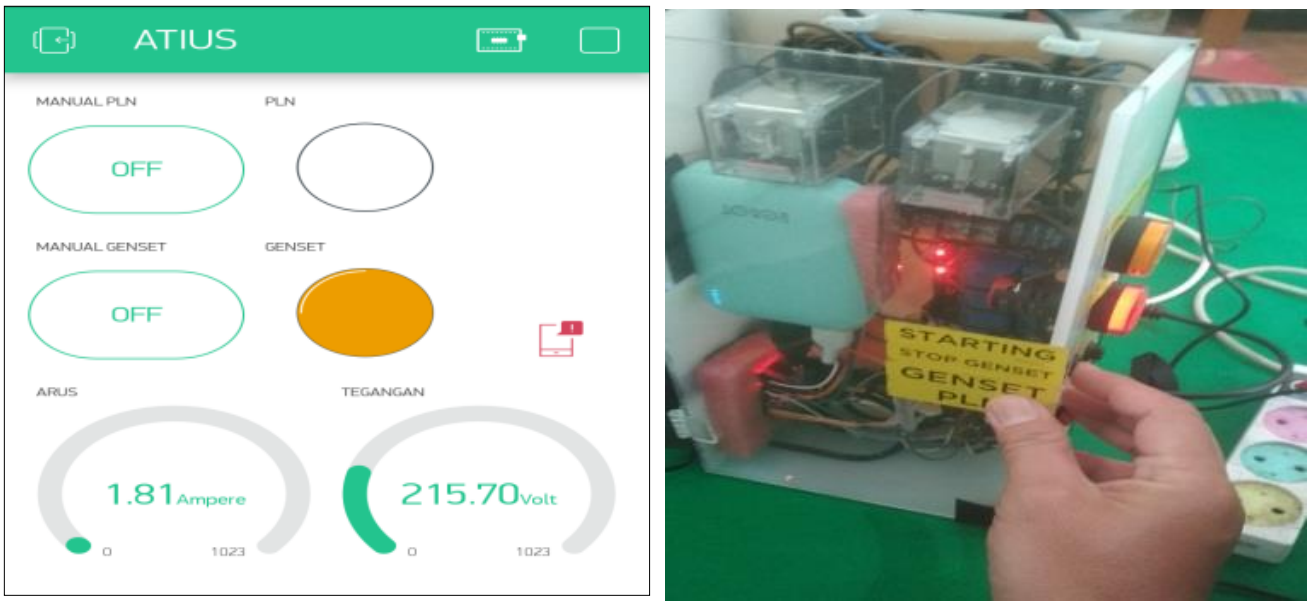

Gambar 20 Kondisi ketika GENSET ON secara Manual menyuplai Beban. 
Tabel 1. Hasil pengujian respon semua relay di 4 kondisi dalam mode otomatis.

\begin{tabular}{ccccccccc}
\hline No & Kondisi & $\begin{array}{c}\text { Relay } \\
\text { AC 1 }\end{array}$ & $\begin{array}{c}\text { Relay } \\
\text { AC 2 }\end{array}$ & $\begin{array}{c}\text { Relay } \\
\text { DC 1 }\end{array}$ & $\begin{array}{c}\text { Relay } \\
\text { DC 2 }\end{array}$ & $\begin{array}{c}\text { Relay } \\
\text { DC 3 }\end{array}$ & $\begin{array}{c}\text { Relay } \\
\text { DC 4 }\end{array}$ & Buzzer \\
\hline 1 & PLN ON, GENSET OFF & ON & OFF & OFF & OFF & OFF & ON & OFF \\
& & & & & & & & \\
2 & PLN OFF, GENSET ON & OFF & ON & ON & OFF & ON & OFF & OFF \\
3 & PLN ON KEMBALI & ON & OFF & OFF & ON & OFF & ON & OFF \\
4 & PLN DAN, GENSET OFF & OFF & OFF & ON & OFF & OFF & OFF & ON \\
\hline
\end{tabular}

Tabel 2 merupakan hasil pengujian yang menyatakan kondisi sumber listrik dikendalikan oleh handphone secara manual.

Tabel 2. Hasil pengujian respon semua relay di 4 kondisi dalam mode manual.

\begin{tabular}{cccccccc}
\hline \multirow{2}{*}{ No } & \multirow{2}{*}{ Kondisi } & $\begin{array}{c}\text { Relay } \\
\text { AC 1 }\end{array}$ & $\begin{array}{c}\text { Relay } \\
\text { AC 2 }\end{array}$ & $\begin{array}{c}\text { Relay } \\
\text { DC 1 }\end{array}$ & $\begin{array}{c}\text { Relay } \\
\text { DC 2 }\end{array}$ & $\begin{array}{c}\text { Relay } \\
\text { DC 3 }\end{array}$ & $\begin{array}{c}\text { Relay } \\
\text { DC 4 }\end{array}$ \\
\hline 1 & PLN OFF, GENSET ON & OFF & ON & ON & OFF & ON & OFF \\
2 & PLN ON, GENSET OFF & ON & OFF & OFF & OFF & OFF & ON \\
\hline
\end{tabular}

Selanjutnya ketika menyalakan generator cadangan dengan menekan tombol GENSET ON pada aplikasi Blynk di handphone, relay DC 1 ON selama 3 detik untuk melakukan starting, proses ini memerlukan delay waktu 2.3 detik setelah tombol ditekan pada handphone. Ketika genset ON, relay AC 2 akan ON tetapi belum menyuplai beban. Setelah 10 detik relay DC 3 akan ON dan tegangan terhubung ke beban.

Ketika tombol aplikasi Blynk ditekan PLN ON, maka relay DC 2 ON dengan respon 2.1 detik setelah tombol ditekan. Relay DC 2 akan ON selama 3 detik untuk mematikan genset dan relay DC 4 ON sehingga beban kembali tersuplai oleh tegangan PLN.

Tabel 3 merupakan hasil pengukuran besar tegangan dan arus pada masing- masing sumber listrik yang dibandingkan dengan pengukuran menggunakan alat ukur multimeter didapatkan nilai kesalahan pembacaan dengan persentase $1.0 \%$. Sehingga alat telah berfungsi dengan baik.

Tabel 3. Hasil pengukuran tegangan dan arus.

\begin{tabular}{cccccccc}
\hline No & $\begin{array}{c}\text { Catu } \\
\text { Daya }\end{array}$ & $\begin{array}{c}\text { Tegangan } \\
\text { Sistem }\end{array}$ & $\begin{array}{c}\text { Tegangan Pada } \\
\text { Multimeter }\end{array}$ & $\begin{array}{c}\text { Error } \\
\text { Tegangan }\end{array}$ & $\begin{array}{c}\text { Arus } \\
\text { Sistem }\end{array}$ & $\begin{array}{c}\text { Arus Pada } \\
\text { Multimeter }\end{array}$ & $\begin{array}{c}\text { Error } \\
\text { Arus }\end{array}$ \\
\hline 1 & PLN & 232.6 & 230.1 & $1.0 \%$ & 0.17 & 0.13 & $1.0 \%$ \\
2 & GENSET & 232.6 & 230.1 & $1.0 \%$ & 0.17 & 0.13 & $1.0 \%$ \\
\hline
\end{tabular}

\subsection{Pengujian Proteksi Overload}

Dalam pengujian ini digunakan beban 1 buah 1 buah Heater, 1 buah setrika dan 1 buah solder. Batasan arus dalam pengujian ini sebesar 3 Ampere. Batasan arus pada pengujian ini berlaku ketika sumber listrik PLN ataupun Genset ON. Sehingga bila terjadi kelebihan arus melebihi batas yang telah ditentukan maka relai pengendali ke beban akan OFF dan mengirim notifikasi ke aplikasi android.

Tabel 4. Hasil pengujian proteksi overload.

\begin{tabular}{cccc}
\hline No & Arus (Ampere) & $\begin{array}{c}\text { Kondisi Relay Kontrol ke } \\
\text { Beban (DC 3/DC 4) }\end{array}$ & Notifikasi pada Aplikasi \\
\hline 1 & 0.74 & ON & OFF \\
2 & 1.39 & ON & OFF \\
3 & 1.68 & ON & OFF \\
4 & 1.94 & ON & OFF \\
5 & 2.15 & ON & OFF \\
6 & 2.30 & ON & OFF \\
7 & 2.85 & ON & OFF \\
8 & 3.20 & OFF & Overcurrent! \\
\hline
\end{tabular}

ISSN (e): 2540-9123

ISSN (p): 2502-1982 
Tabel 4 merupakan hasil pengujian proteksi overload dilakukan dengan besar arus yang berbeda dari 0.74 Ampere sampai 3.20 Ampere. Ketika besar arus masih dibawah 3.00 Ampere notifikasi belum aktif. Setelah terbaca arus sebesar 3.20 Ampere maka relay kontrol akan OFF sehingga memutuskan suplai listrik dari sumber ke beban dan mengirimkan sebuah notifikasi berupa text "Overcurrent!" pada aplikasi android serta smatphone android akan berdering.

\subsection{Pengujian Proteksi Down Voltage}

Dalam pengujian proteksi down voltage, tegangan dibatasi untuk tegangan minimal 200 Volt. Pengujian menggunakan autotrafo untuk mensimulasikan penurunan tegangan sumber listrik.

Tabel 5. Hasil pengujian proteksi down voltage.

\begin{tabular}{cccc}
\hline No & Tegangan (Volt) & $\begin{array}{c}\text { Kondisi Relay Kontrol ke } \\
\text { Beban (DC 3/DC 4) }\end{array}$ & $\begin{array}{c}\text { Notifikasi } \\
\text { pada Aplikasi }\end{array}$ \\
\hline 1 & 225.30 & ON & OFF \\
2 & 221.50 & ON & OFF \\
3 & 221.80 & ON & OFF \\
4 & 216.80 & ON & OFF \\
5 & 216.50 & ON & OFF \\
6 & 214.00 & ON & OFF \\
7 & 210.30 & ON & OFF \\
8 & 198.00 & OFF & Undervoltage \\
\hline
\end{tabular}

Tabel 5 merupakan hasil pengujian proteksi downvoltage dilakukan dengan besar tegangan yang berbeda dari 225.30 Volt sampai 198.00 Volt. Ketika besar tegangan masih diatas 200 Volt notifikasi belum aktif. Setelah terbaca arus sebesar 198.00 Volt maka relai kontrol akan OFF sehingga memutuskan suplai listrik dari sumber ke beban dan mengirimkan sebuah notifikasi berupa teks "Undervoltage " pada aplikasi android serta smatphone android akan berdering.

\section{Kesimpulan}

Berdasarkan hasil pengujian, dapat disimpulkan beberapa hasil penelitian yaitu: 1). Sistem Automatic Transfer Switch (ATS) yang terhubung ke internet dengan cloud server Blynk dapat bekerja dengan baik dalam pemantauan dan pengendalian suplai daya listrik dari sumber ke beban melalui aplikasi Blynk pada Android dengan dengan rata-rata selisih pembacaan \pm 2 volt atau dalam persentase kesalahan sebesar $1.0 \% ; 2$ ). Sistem pengaman terhadap gangguan kelebihan beban (overload) dan penurunan tegangan sumber (downvoltage) berupa peringatan yang muncul teks dan suara dering untuk overload dengan batas arus 3 Ampere dan untuk penurunan tegangan minimal 200 Volt telah bekerja dengan baik. Sistem memutuskan hubungan sumber listrik ke beban ketika terbaca tegangan sumber listrik sebesar 198.00 volt dan ketika terbaca arus sebesar 3.20 Ampere; 3). Respon relay ketika tombol pada handphone ditekan sebesar 2.3 detik.

\section{Referensi}

[1] R. Pakhpahan, D. . Ramadhan, and S. Hadiyono, "Rancang Bangun dan Implementasi Automatic Transfer Switch (ATS) Menggunakan Arduino Uno dan Relai.," JETT, vol. 3, no. 2, pp. 332-341, 2016.

[2] A. Pandey, A. Azhar, A. Gautam, and M. Tiwari, "IOT Based Home Automation Using Arduino and ESP8266," International Journal of Computer Sciences and Engineering, vol. 6, no. 4, pp. 267-270, 2018.

[3] A. Reinald Madjid and B. Suprianto, "Prototype Monitoring Arus, dan Suhu Pada Transformator Distribusi Berbasis Internet of Things (IoT)," Universitas Negeri Surabaya, vol. 8, pp. 111-119, 2019. 
[4] I. G. P. M. Eka Putra, I. A. Dwi Giriantari, and L. Jasa, "Monitoring Menggunaan Daya Listrik Sebagai Implementasi Internet of Things Berbasis Wireless Sensor Network," Universitas Udayana, vol. 16, pp. 50-55, 2017.

[5] H. Utomo, A. Sadnowo, and S. Ratna, "Implementasi Automatic Transfer Switch Berbasis PLC pada Laboratorium Teknik Elektronika Jurusan Teknik Elektro Universitas Lampung," 2014.

[6] Lutfianto, Faqih Rofi'i, and M. Mukhsim, "Sistem Pengendalian Generator Set Secara Wireless Berbasis Arduino dengan Modbus TCP dan Logika Fuzzy," Fakultas Teknik Universitas Maarif Hasyim Latif, vol. 2, no. 1, pp. 1-10, Jun. 2018.

[7] W. Sunanda and I. Dinata, "Penerapan Perangkat Wireless Monitoring Energi Listrik Berbasis Arduino dan Internet," Universitas Bangka Belitung, vol. 04, pp. 21-23, 2014.

[8] H. Nur Isnianto and E. Puspitaningrum, "Monitoring Tegangan, Arus, Dan Daya Secara Real Time untuk Perbaikan Faktor Daya Secara Otomatispada Jaringan Listrik Satu Fase Berbasis Arduino," JNTT Universitas Gadjah Mada, vol. 2, pp. 31-36, 2018.

[9] F. Nur Habibi, S. Setiawidayat, and M. Mukhsim, "Alat Monitoring Pemakaian Energi Listrik Berbasis Android Menggunakan Modul PZEM-004T," Prosiding Seminar Nasional Teknologi Elektro Terapan 2017, vol. 01, pp. 157-162, 2017.

[10] G. Permata, S. Setiawidayat, and H. Fachrudin, "Pemantauan Energi dan Pengiriman Data Kinerja Transformator Menggunakan Web," Jurnal Ilmiah Widya Teknika Universitas Widyagama Malang, vol. 26, no. 2, pp. 182-193, 2018.

[11] H. S. Doshi, M. S. Shah, and U. S A Shaikh, "Internet of Thinghs (IoT): Integration of Blynk for Domestic Usability," VJER-Vishwakarma Journal of Engineering Research, vol. 1, no. 4, pp. 150-157, 2017.

[12] A. Junaidi, "Internet of Things, Sejarah, Teknologi dan Penerapannya : Review," Jitter Widyatama, vol. 1, pp. 62-66, 2015. 